УДК 349.2

DOI https://doi.org/10.32849/2663-5313/2020.11.12

\title{
Яна Сімутіна,
}

докт. юрид. наук, старший науковий співробітник, провідний науковий співробітник відділу проблем иивільного, трудового та підприємницького права

Інституту держави і права імені В.М. Корещького

Національної академії наук України

\section{УКЛАДЕННЯ СТРОКОВИХ ТРУДОВИХ ДОГОВОРІВ ІЗ ПЕДАГОГІЧНИМИ ПРАЦВНИКАМИ ПЕНСІЙНОГО ВІКУ: ДИФЕРЕНЦІАЦІЯ ЧИ ДИСКРИМІНАЦІЯ?}

У статті досліджується питання щодо запровадження строковихтрудових договорів для педагогічних прачівників державних і комунальних закладів загальної середньої освіти, які досягли пенсійно20 віку й отримують пенсію за віком, у контексті співвідношення понять диференціації та дискримінаиії у трудовому праві. Наголошується, що в окремих випадках норми, спрямовані на диференціацію у сфері прачі, можуть бути не завжди обгрунтованими, мати дискримінаційний характер, а їх реалізація може призвести до порушення принципу рівності та можливостей прачівників. Проаналізовано невідповідність передбаченої в положеннях абзаиу 3 частини 2 статті 22 Закону України «Про повну загальну середню освіту» норми щодо укладення з педагогічними прачівниками державних $і$ комунальних закладів загальної середньої освіти, які досягли пенсійного віку та яким виплачується пенсія за віком, лише строкового трудового договору (строком від одного до трьох років) низиі міжнародних та європейських актів. Зважаючи на загальне правило щодо обмеженої сфери укладання трудового договору на невизначений термін (частина 2 статті 23 Кодексу законів про прачю України), строковий трудовий договір є таким, що погіршує правове становище прачівника, адже щоразу зі спливом строку дії трудового договору подальше існування трудових правовідносин залежить від рішення роботодавия. Отже, запровадження обов'язкового укладення з педагогічними прачівниками, які досягли пенсійного віку й отримують пенсію за віком, лише строкових трудових договорів (строком від одного до трьох років) порушує ӥхнє конституиійне право на праию. Під час порівняння правового становища педагогічних працівників пенсійного віку та педагогічних прачівників, які не досягли пенсійного віку, зроблено висновок про відсутність легітимної мети, а отже, розумного й об'єктивного обгрунтування диферениіації правового регулювання педагогічних прачівників, які досягли пенсійного віку, у частині строку дії трудових договорів. Констатовано, що укладення виключно строкових трудових договорів із педагогічними працівниками пенсійного віку, які отримують пенсію за віком, порушує гарантії, закріплені в частині 2 статті 24 Конституиії України, та за віковою ознакою є прямою дискриміначією зазначеної категорії літніх осіб у реалізацї̈ їхнвого права на пращю.

Ключові слова: строковий трудовий договір, дискримінація, диференціація, педагогічні працівники, пенсійний вік, трудові відносини, незаконне звільнення, порушення права на працю.

Постановка проблеми. Єдність та диференціація правового регулювання є однією 3 особливостей трудового права як самостійної галузі. Єдність передбачає наявність загальних правил регулювання відносин у сфері праці, диференціація - встановлення відмінностей за допомогою спеціальних норм, які покликані враховувати наявні особливості об'єктивного (пов’язані зі специфікою окремих видів роботи) та суб'єктивного (пов'язані з особою працівника) характеру.

У доктрині трудового права сформувалися певні підходи щодо диференціації правового регулювання. Зокрема, будь-яка диференціація у сфері праці має спиратися на чіткі, зрозумілі та справедливі підстави; вона має бути обгрунтованою; мати визначену мету, бути сумірною із цією метою. На думку I.C. Сахарук, диференціація норм трудового права має велике значення для фактичного забезпечення рівності можливостей під час реалізації трудових прав [1, с. 49].

Правовим антиподом диференціації є дискримінація [2, с. 262]. Термін «дискримінація» походить від лат. і означає «розрізняю», «розділяю». Стосовно трудового права йдеться про такі відмінності, які обмежують 
чи унеможливлюють реалізацію трудових прав на засадах рівності [3, с. 100].

Як показує досвід, у деяких випадках норми, спрямовані на диференціацію у сфері праці, можуть бути не завжди обгрунтованими, мати дискримінаційний характер, a їх реалізація може призвести до порушення принципу рівності прав і можливостей працівників.

Питання диференціації правового регулювання, як i проблеми дискримінації, належно досліджені в науці трудового права. Першими цікавилися, зокрема, такі вчені, як: В.Я. Бурак, О.І. Процевський, О.М. Ярошенко й інші. Дискримінація у трудовому праві була предметом вивчення в кандидатській дисертації І.С. Сахарук. Водночас комплексні теоретичні дослідження цих двох категорій у їхньому взаємозв'язку в науці трудового права нині відсутні. Однак ці питання набувають особливої актуальності з огляду на появу в новому Законі України «Про повну загальну середню освіту» від 16 січня 2020 р. № 463-IX [4] норми щодо залучення до роботи педагогічних працівників пенсійного віку виключно на підставі строкових трудових договорів, саме в контексті співвідношення понять диференціації та дискримінації у трудовому праві.

Метою статті $є$ обгрунтування дискримінаційного характеру норми абз. 3 ч. 2 ст. 22 Закону України «Про повну загальну середню освіту», у якій закріплена диференціація строку дії трудового договору з педагогічними працівниками державних і комунальних закладів загальної середньої освіти, які досягли пенсійного віку й отримують пенсію за віком.

Виклад основного матеріалу. Відповідно до абз. 2 ч. 2 ст. 22 Закону України «Про повну загальну середню освіту», педагогічні працівники закладів освіти приймаються на роботу за трудовими договорами згідно з вимогами цього Закону та законодавства про працю. Водночас в абз. 3 цієї ж частини застосований диференційований підхід до педагогічних працівників державних і комунальних закладів загальної середньої освіти, які досягли пенсійного віку й отримують пенсію за віком, зокрема щодо обов'язкової строковості укладених із ними трудових договорів.

Навіть більше, у п. 2 ч. 3 розд. $\mathrm{X}$ «Прикінцеві та перехідні положення» передбачено, що набрання чинності цим Законом є підставою для припинення безстрокового трудового договору з педагогічними працівниками державних і комунальних закладів загальної середньої освіти, яким виплачується пенсія за віком, згідно з п. 9 ч. 1 ст. 36 Кодексу законів про працю України.

Отже, керівники державних і комунальних закладів загальної середньої освіти до 1 липня 2020 р. були зобов'язані припинити безстрокові трудові договори 3 педагогічними працівниками таких закладів освіти, яким виплачується пенсія за віком, з одночасним укладенням із ними трудових договорів строком на один рік. У разі незгоди із продовженням трудових відносин на умовах строкового трудового договору педагогічні працівники, яким виплачується пенсія за віком, повинні бути звільнені згідно 3 п. 9 ч. 1 ст. 36 Кодексу законів про працю України.

Аналіз наведених вище законодавчих положень дає підстави констатувати таке. По-перше, вимога щодо укладення строкових трудових договорів встановлена лише для працівників державних i комунальних закладів загальної середньої освіти. По-друге, вона стосується тільки працівників, що мають статус педагогічних. По-третє, норма щодо укладення строкових трудових договорів поширюється лише на педагогічних працівників пенсійного віку, яким виплачується пенсія за віком. Тобто лише досягнення працівником пенсійного віку ще не дає роботодавцю підстав для укладення строкового трудового договору. По-четверте, норма про укладення строкових трудових договорів стосується осіб, які отримують пенсію за віком. Водночас вона не може бути застосована до осіб, які досягли пенсійного віку, але яким виплачуються інші види пенсій, наприклад, пенсій по інвалідності, у разі втрати годувальника, за вислугу років, пенсії за спеціальними законами («Про державну службу», «Про наукову та науково-технічну діяльність», «Про пенсійне забезпечення осіб, звільнених з військової служби, та деяких інших осіб» тощо).

3 огляду на зазначене вище виникає питання щодо наявності легітимної мети, якою керувався законодавець під час запровадження обов'язкових строкових трудових договорів саме для педагогічних працівників державних і комунальних закладів загальної середньої освіти, які досягли пенсійного віку й отримують саме такий вид пенсії, як пенсія за віком, та взагалі необхідності диференціювати правове регулювання строку дії трудових договорів цієї категорії працівників.

Для повноти дослідження необхідно звернутися до аналізу відповідних положень Конституції України, європейських та міжнародних нормативно-правових актів щодо протидії та запобіганню будь-яким проявам дискримінації, зокрема й за віковою озна- 
кою, а також щодо гарантованої та стабільної зайнятості.

Так, у ч. ч. 1, 2 ст. 24 Конституції України проголошено рівність конституційних прав і свобод громадян. Зокрема, не може бути привілеїв чи обмежень за ознаками раси, кольору шкіри, політичних, релігійних та інших переконань, статі, етнічного та соціального походження, майнового стану, місця проживання, за мовними або іншими ознаками.

Згідно зі ст. 1 Європейської соціальної хартії (переглянутої), ратифікованої Законом України від 14 вересня 2006 р. № 137-V [5], з метою забезпечення ефективного здійснення права на працю сторони зобов'язуються визнати однією із своїх найголовніших цілей і одним із своїх найголовніших обов'язків досягнення та підтримання якомога високого і стабільного рівня зайнятості, маючи на меті досягнення повної зайнятості; ефективно захищати право працівника заробляти собі на життя професією, яку він вільно обирає. 3 метою забезпечення ефективного здійснення права працівників на захист у разі звільнення сторони зобов'язуються визнати: а) право всіх працівників не бути звільненими без поважних причин для такого звільнення, пов'язаних з їхньою працездатністю чи поведінкою, або поточними потребами підприємства, установи чи служби; б) право працівників, звільнених без поважної причини, на належну компенсацію або іншу відповідну допомогу. Із цією метою сторони зобов'язуються забезпечити, щоб кожний працівник, який уважає себе звільненим без поважної причини, мав право на оскарження в неупередженому органі (ст. 24 Хартії).

у Конвенції Міжнародної організації праці (далі - МОП) № 158 про припинення трудових відносин з ініціативи роботодавця [6] закріплено положення щодо необхідності забезпечувати адекватні гарантійні заходи проти застосування договорів про найм на визначений термін, мета яких - ухилитися від надання захисту, передбаченого цією Конвенцією (тобто захисту від невиправданого звільнення). Крім того, Конвенцією встановлено, що трудові відносини із працівниками не припиняються, якщо тільки немає законних підстав для такого припинення, пов'язаного зі здібностями чи поведінкою працівника або викликаного виробничою потребою підприємства, установи чи служби (ст. 4).

У Рекомендації МОП 1982 р. № 166 щодо припинення трудових відносин [7] передбачено, що, крім підстав, зазначених у ст. $5 \mathrm{KoH}^{-}$ венції МОП № 158 про припинення трудових відносин, законною підставою для припинення трудових відносин не повинна бути така причина, як вік, залежно від національних законодавства і практики, що стосуються виходу на пенсію. Однією з гарантії масштабного укладання строкових трудових договорів мають стати обмеження застосування строкових трудових договорів випадками, коли, з огляду на рід майбутньої роботи або умови її виконання, а також інтереси працівників, ці трудові відносини не можуть встановлюватися безстроково.

Рекомендація МОП № 162 щодо літніх працівників [8] прямо передбачає обов'язок кожної держави - члена МОП у рамках національної політики, спрямованої на сприяння рівності ставлення та можливостей для працівників незалежно від їхнього віку, та в рамках законодавства і практики в цій галузі вживати заходів до недопущення дискримінації літніх працівників у сфері праці та занять.

Літні працівники без дискримінації за віком повинні користуватися рівністю можливостей та ставлення нарівні 3 іншими працівниками, зокрема щодо: а) доступу до служб професійної орієнтації та працевлаштування; b) доступу, з урахуванням їхніх особистих здібностей, досвіду та кваліфікації: до роботи за їхнім вибором як у державному, так і у приватному секторах: однак у виняткових випадках можуть встановлюватись вікові обмеження з огляду на особливі вимоги, умови або правила для деяких видів роботи; до можливостей професійної підготовки, зокрема підвищення кваліфікації та перекваліфікації; до оплачуваної навчальної відпустки, зокрема з метою професійної підготовки та профспілкової освіти; до просування по службі та справедливого розподілу роботи (п. 5 Рекомендації МОП № 162).

Директива Ради 1999/70/ЄС від 28 червня 1999 р. щодо рамкової угоди про роботу на визначений термін, укладеної Європейською асоціацією профспілок, Союзом конфедерацій промисловців та підприємців Європи та Європейським центром підприємств із державною участю (ETUC, UNICE та CEEP), закріпила положення, що сторони цієї угоди визнають, що договори невизначеної тривалості є та будуть основною формою трудових відносин між підприємцями та працівниками. Вони також визнають, що трудові договори на невизначений термін $є$ основною формою трудових відносин, сприяють якості життя зацікавлених працівників та покращують роботу; використання трудових договорів на визначений термін, основаних на об'єктивних причинах, є способом запобігання зловживанню; трудові договори на 
визначений термін $є$ особливістю зайнятості в деяких секторах, справах та діяльності, які можуть задовольнити і підприємців, і працівників. Цілями цієї угоди є поліпшення якості роботи з визначеним терміном, із забезпеченням застосування принципу недискримінації; встановлення обмежень для запобігання зловживанню, яке є наслідком використання послідовних трудових договорів або відносин на визначений термін [9]

Отже, законодавче закріплення вимоги щодо укладення строкових трудових договорів із педагогічними працівниками державних і комунальних закладів загальної середньої освіти, які досягли пенсійного віку й отримують пенсію за віком, суперечить низці міжнародних та європейських документів.

Основним нормативно-правовим актом, який регулює відносини у сфері використання найманої праці та встановлює основні трудові права працівників, є Кодекс законів про працю України (далі - КЗпП України).

Зі змісту ст. 2-1 КЗпП України «Рівність трудових прав громадян України» зрозуміло, що забороняється будь-яка дискримінація у сфері праці, зокрема порушення принципу рівності прав і можливостей, пряме або непряме обмеження прав працівників залежно від раси, кольору шкіри, політичних, релігійних та інших переконань, статі, гендерної ідентичності, сексуальної орієнтації, етнічного, соціального й іноземного походження, віку, стану здоров'я, інвалідності, підозри чи наявності захворювання на ВІЛ/ СНІД, сімейного та майнового стану, сімейних обов'язків, місця проживання, членства у професійній спілці чи іншому об'єднанні громадян, участі у страйку, звернення або наміру звернення до суду чи інших органів за захистом своїх прав або надання підтримки іншим працівникам у захисті їхніх прав, за мовними або іншими ознаками, не пов'язаними 3 характером роботи або умовами її виконання [10].

Відповідно до ст. 6 Закону України «Про засади запобігання та протидії дискримінації в Україні», усі особи незалежно від іххніх певних ознак мають рівні права і свободи, а також рівні можливості для їх реалізації [11].

Положення згаданої вище Рекомендації МОП № 162 щодо літніх працівників знайшли відображення в нормах Закону України «Про основні засади соціального захисту ветеранів праці та інших громадян похилого віку в Україні» від 16 грудня 1993 р. № 3721 XII. Так, у ч. 2 ч. та 3 ст. 2 цього Закону передбачено, що громадяни похилого віку (згідно зі ст. 10 цього Закону, це особи, які досягли пенсійного віку, встановленого ст. 26 Закону
України «Про загальнообов'язкове державне пенсійне страхування», а також особи, яким до досягнення зазначеного пенсійного віку залишилося не більш як півтора року) користуються всіма соціально-економічними й особистими правами і свободами, закріпленими Конституцією України, іншими законодавчими актами. Закон забороняє дискримінацію громадян похилого віку в галузі праці, охорони здоров'я, соціального забезпечення, користування житлом та в інших сферах [12].

Відповідно до ст. ст. 11, 12 Закону України «Про основні засади соціального захисту ветеранів праці та інших громадян похилого віку в Україні», громадяни похилого віку мають право на працю нарівні з іншими громадянами, яке додатково гарантується державними цільовими програмами, територіальними та місцевими програмами зайнятості населення. Умови договорів про працю (контрактів, угод) із громадянами похилого віку не можуть погіршувати становище або обмежувати їхні права, передбачені законодавством про працю. Такі умови є недійсними.

Під час розгляду питання щодо законності й доцільності диференціації строку дії трудового договору педагогічних працівників пенсійного віку не можна залишити поза увагою рішення Конституційного Суду України від 16 жовтня 2007 р. № 8-рп/2007 у справі за конституційним поданням 47 народних депутатів України щодо відповідності Конституції України (конституційності) положень ст. 23 Закону України «Про державну службу», ст. 18 Закону України «Про службу в органах місцевого самоврядування», ст. 42 Закону України «Про дипломатичну службу» (справа про граничний вік перебування на державній службі та на службі в органах місцевого самоврядування).

У цьому рішенні Конституційний Суд, зокрема, зазначив, що гарантовані ч. 1 ст. 24 Конституції України рівність прав і свобод громадян та їхня рівність перед законом, а також неприпустимість привілеїв чи обмежень за ознаками, визначеними ч. 2 цієі статті, не перешкоджають встановлювати відмінності у правовому регулюванні праці щодо осіб, які належать до різних за родом і умовами діяльності категорій [13].

Однак, на наш погляд, встановлення відмінностей у правовому регулюванні праці однорідної за родом і умовами діяльності категорії педагогічних працівників державних і комунальних закладів загальної середньої освіти, зокрема встановлення вимоги укладати строкові трудові договори (на строк від одного до двох років) для педагогічних працівників пенсійного віку, які отримують 
пенсії за віком, та, окрім цього, нічим не відрізняються від інших педагогічних працівників таких закладів освіти, має всі ознаки прямої дискримінації.

Окрім цього, досліджувана нами проблема має й інший аспект, оскільки у трудовому праві загальновизнаний принцип стабільності трудових відносин. Ст. 5-1 КЗпП України встановлює, що держава гарантує працездатним громадянам, які постійно проживають на території України, серед іншого, правовий захист від необгрунтованої відмови у прийнятті на роботу і незаконного звільнення, а також сприяння у збереженні роботи.

Працівники укладають трудовий договір для того, щоб мати постійне джерело засобів для існування себе і своєї сім’ї. Тому вони зацікавлені в тому, щоб їхні відносини 3 підприємством, установою, організацією, з якими вони уклали трудовий договір, були тривалими і стабільними. У тривалості і стабільності трудових відносин проявляється гарантія зайнятості тих, хто працює. Саме тому за загальним правилом трудовий договір укладається на невизначений термін. Закон віддає перевагу такого виду договорам, оскільки вони сприяють стабільності трудових правовідносин, а також забезпечують належний рівень гарантій трудових прав найманих працівників.

3 огляду на цю обставину, а також зважаючи на принцип стабільності трудових правовідносин та загальне правило щодо обмеженої сфери укладання трудового договору на невизначений термін (ч. 2 ст. 23 КЗпП України), строковий трудовий договір можна вважати таким, що у своїй основі погіршуе правове становище працівника, робить його менш вигідним порівняно з договором на невизначений строк. У разі укладення трудового договору на певний строк всупереч установленим у ст. 23 КЗпП України правилам такий трудовий договір має бути визнаний недійсним у частині його строку. У зв'язку зі цим також можна стверджувати, що укладення 3 педагогічними працівниками, які досягли пенсійного віку та яким виплачується пенсія за віком, лише строкового трудового договору (строком від одного до трьох років), зменшує рівень конституційних гарантій права на працю в частині захисту від незаконного звільнення, передбаченого ч. 6 ст. 43 Конституції України.

\section{Висновки}

На підставі викладеного можна констатувати таке:

1. Пенсійний вік не є визначальним критерієм, прийнятним для запровадження обов'язковості укладення 3 педагогічними працівниками державних і комунальних закладів загальної середньої освіти лише строкових трудових договорів. У зв'язку із цим досягнення педагогічним працівником пенсійного віку й отримання ним пенсії за віком не може вважатися об'єктивною обставиною, що впливає на обов'язковість укладення з ним строкового трудового договору на певний обмежений строк, оскільки ця обставина не змінює правового статусу такого педагогічного працівника, його професійних обов'язків, інших умов трудової діяльності тощо.

2. Зважаючи на принцип стабільності трудових правовідносин та загальне правило щодо обмеженої сфери укладання трудового договору на невизначений термін (ч. 2 ст. 23 КЗпП України), строковий трудовий договір є таким, що погіршує правове становище працівника, робить його менш вигідним порівняно з договором на невизначений строк, адже щоразу зі спливом строку дії трудового договору подальше існування трудових правовідносин залежить від рішення роботодавця. Отже, запровадження обов'язкового укладення 3 педагогічними працівниками державних і комунальних закладів загальної середньої освіти, які досягли пенсійного віку й отримують пенсію за віком, лише строкових трудових договорів (строком від одного до трьох років) порушує конституційне право на працю, гарантоване ч. 1 ст. 43 Основного закону України.

3. Строк, на який можна укласти трудовий договір із педагогічним працівником, який досягнув пенсійного віку, законодавцем визначено від одного до трьох років. Однак водночас законодавець не передбачив критерії, відповідно до яких має визначатися конкретний строк на заміщення посади. Це питання фактично залишено на розсуд роботодавця та необмежене жодними законодавчими вимогами. Невизначеність критеріїв для встановлення строку, на який має бути укладено трудовий договір на певну посаду в межах можливого строку, призведе до того, що всі педагогічні працівники пенсійного віку, які отримують пенсію за віком, опиняються залежними від роботодавця щодо зайняття посад або продовження терміну дії трудового договору, а законодавець фактично уможливив безпідставну відмову в зайнятті посади або звільнення $з$ неї у зв'язку із закінченням строку дії трудового договору, зменшив рівень конституційних гарантій права на працю в частині захисту від незаконного звільнення, передбаченого ч. 6 ст. 43 Конституції України. 
4. Передбачена в положеннях абз. 3 ч. 2 ст. 22 Закону України «Про повну загальну середню освіту» вимога щодо укладення 3 педагогічними працівниками державних і комунальних закладів загальної середньої освіти, які досягли пенсійного віку та яким виплачується пенсія за віком, лише строкового трудового договору (строком від одного до трьох років), є дискримінаційною стосовно цієї категорії педагогічних працівників. У разі порівняння їхнього становища та педагогічних працівників, які не досягли пенсійного віку, варто констатувати відсутність легітимної мети таких заходів, а отже, розумного й об'єктивного обгрунтування диференціації правового регулювання педагогічних працівників, які досягли пенсійного віку, у частині строку дії трудових договорів.

У зв'язку із цим норми Закону України «Про повну загальну середню світу», якими передбачено укладення виключно строкових трудових договорів із педагогічними працівниками пенсійного віку, які отримують пенсію за віком, варто визнати такими, що всупереч вимогам ч. 2 ст. 24 Конституції України, за віковою ознакою нині дискримінують окрему категорію літніх громадян у реалізації їхнього права на працю.

\section{Список використаних джерел:}

1. Сахарук І.С. Правове регулювання рівних прав і можливостей окремих категорій працівників. Науковий вісник Чернівеиького університету. Серія «Правознавство». 2010. Вип. 533. С. 49. URL: http://lawreview.chnu.edu.ua/visnuku/st/ 533/9.pdf.

2. Красноярова Е.В. Дифференциация как правовой антипод дискриминации. Вестник Иркутского государственного технического университета. 2014. № 2 (85). С. 261.

3. Вишновецька С.В. Дискримінація у трудовому праві. Велика украйнська юридична енииклопедія : у 20-ти т. / редкол. : С.М. Прилипко та ін. ; Нац. акад. прав. наук України ; Ін-т держави і права ім. В.М. Корецького НАН України ; Нац. юрид. ун-т ім. Ярослава Мудрого. 2018. Т. 11 : Трудове право. С. 100.

4. Про повну загальну середню освіту : Закон України від 16 січня 2020 р. № 463-IX. URL https://zakon.rada.gov.ua/laws/show/463-20?find= $1 \&$ text $=\% \mathrm{D} 0 \% \mathrm{BF} \% \mathrm{D} 0 \% \mathrm{~B} 5 \% \mathrm{D} 0 \% \mathrm{BD} \% \mathrm{D} 1 \% 81 \% \mathrm{D}$ 1\%96\#w1_3.

5. Європейська соціальна хартія (переглянута) від 3 травня 1996 р., ратифікована із заявами Законом України від 14 вересня 2006 р. № 137-V. URL: https://zakon.rada.gov.ua/laws/ show/994 062\#Text.

6. Конвенція Міжнародної організації праці № 158 про припинення трудових відносин ініціативи роботодавця 1982 p. URL: https:// zakon.rada.gov.ua/laws/show/993 005\#Text.

7. Рекомендація МОП № 166 щодо припинення трудових відносин 1982 p. URL: https:// zakon.rada.gov.ua/laws/show/993 276\#Text.

8. Рекомендація МОП № 162 щодо літніх працівників 1980 р. URL: https://zakon.rada.gov.ua/ laws/show/993_089\#Text.

9. Директива Ради 1999/70/СС від 28 червня 1999 р. щодо рамкової угоди про роботу на визначений термін, укладеної ETUC, UNICE та CEEP (Європейською асоціацією профспілок, Союзом конфедерацій промисловців та підприємців Європи та Європейським центром підприємств із державною участю). URL: https://eur-lex.europa.eu/eli/ $\operatorname{dir} / 1999 / 70 /$ oj.

10. Кодекс законів про працю України від 10 грудня 1971 р. № 322-VIII. URL: https:/ zakon.rada.gov.ua/laws/show/322-08\#Text.

11. Про засади запобігання та протидії дискримінації в Україні : Закон України від 6 вересня 2012 p. № 5207-VI. URL: https://zakon.rada.gov.ua/ laws/show/5207-17\#Text.

12. Про основні засади соціального захисту ветеранів праці та інших громадян похилого віку в Україні : Закон України від 16 грудня 1993 р. № 3721-XII. URL: https://zakon.rada.gov.ua/laws/ show/3721-12\#Text.

13. Рішення Конституційного Суду України від 16 жовтня 2007 р. № 8-рп/2007. URL: http:// ccu.gov.ua/docs/555.

Yana Simutina. Conclusion of fixed-term employment contracts with pedagogical workers of retirement age: differentiation or discrimination?

The article examines the introduction of fixed-term employment contracts for pedagogical workers of state and municipal institutions of general secondary education who have reached the retirement age and receive an age pension in the context of differentiation and discrimination in labour law.

It is emphasized that in some cases, the norms aimed at differentiation in the field of labour may not always be justified, but discriminatory, and their implementation may lead to a violation of the principle of equality and opportunities for workers. The author drawes attention to the inconsistency of the Article 22 of the Law of Ukraine "On Complete General Secondary Education" about the conclusion of only a fixedterm employment contract with pedagogical workers of state and municipal institutions with a number of international and European acts. Given the general rule on the limited scope of the employment contract for an indefinite period (Part 2 of Article 23 of the Labour Code of Ukraine), a fixed-term employment contract worsens the legal status of the employee, because each time with the expiration of the employment contract, the continued existence of the employment relationship depends on the decision of the employer. Thus, concluding fixed-term employment contracts (for a period of one to three years) with pedagogical workers 
who have reached retirement age and receive an age pension may violate their constitutional right to work. When comparing the legal status of teachers of retirement age with teachers who have not reached retirement age, it is concluded that there is no legitimate goal, and therefore a reasonable and objective justification for the differentiation of legal regulation in terms of employment contracts. It is stated that the conclusion of fixed-term employment contracts with pedagogical workers of retirement age who receive an age pension violates the guarantees enshrined in the second part of Article 24 of the Constitution of Ukraine, and it seems to be a direct age discrimination of this category of elderly people in exercising their right to work.

Key words: fixed-term employment contract, discrimination, differentiation, pedagogical workers, retirement age, labor relations, illegal dismissal, violation of right to work. 